Branch"@2020.

Available online

\title{
"RELATIONSHIP BETWEEN IMPACTED MANDIBULAR THIRD MOLAR AND MANDIBULAR CANAL” DOES CONE BEAM COMPUTED TOMOGRAPHY IMAGING PROMISE MORE EFFECTIVE DIAGNOSIS BEFORE EXTRACTION THAN ORTHOPANTAMOGRAPH? - A SYSTEMATIC REVIEW
}

Dr.Sanjana.S, Dr. DivyaLalitha.N, Dr. Prabu. D, Dr. Sunayana Manipal, Dr. Rajmohan, Dr. Bharathwaj.V.V Department of Public Health Dentistry, SRM Dental College, Ramapuram, Chennai, Tamilnadu, India.

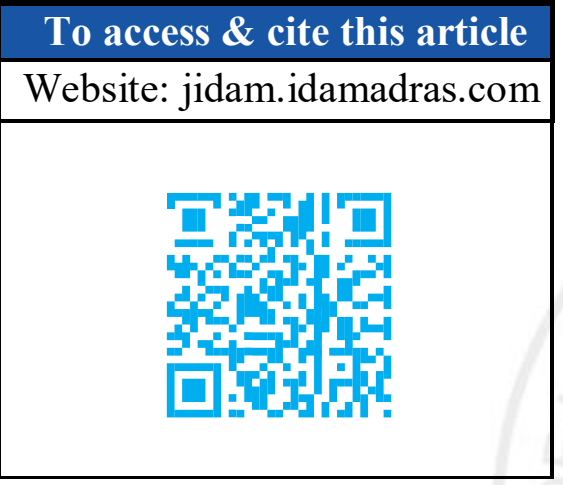

DOI:10.37841/jidam_2020_V7_I3_01

\section{Address for Correspondence:}

Dr. DivyaLalitha. N., MDS, Department of Public Health Dentistry, SRM Dental College, Ramapuram, Chennai-600089, Tamilnadu, India Email id: diyan2409@gmail.com

$\begin{array}{ll}\text { Received } & : 26.08 .2020 \\ \text { Accepted } & : 15.09 .2020 \\ \text { Published } & : 27.09 .2020\end{array}$

\begin{abstract}
BACKGROUND: Proper diagnosis of impacted mandibular third molars (IMTM) is essential to prevent injury at the site during extraction and aftermath surgical complications. OPG (Orthopantomograph) is the most common diagnostic aid followed nowadays. However, since the two dimensional imaging does not provide adequate details for diagnosis, CBCT (Cone-Beam Computed Tomography) is preferred in order to avoid such impediments as it provides higher quality imaging and makes the extraction procedure much easier with its ample detailing for diagnosis.
\end{abstract}

AIM: To compare preoperative radiography with cone-beam computed tomography in the assessment of the relationship between impacted mandibular third molar and mandibular canal.

METHOD: A systematic review of the records comparing panaromic radiography with cone-beam computed tomography for the preoperative assessment of impacted mandibular third molar and its relationship with the mandibular canal was done. A literature review was performed using Medline, Pubmed, Science direct, and Cochrane. Total of 383 articles appeared from various sources; all articles were screened and 15 were related to the research question. This review was reported according to the PRISMA guidelines.

RESULTS: With the 15 articles included in the systematic review as qualitative synthesis, the presence of darkening of roots and interruption of the white line in OPG, as both separate findings and in association with each other are effective in influencing the risk relationship between IMTM and mandibular canal, which further certainly require a $3 \mathrm{D}$ evaluation $(\mathrm{CBCT})$ before performing the surgery.

CONCLUSON: CBCT imaging provides much a promising evaluation in determining the relationship between impacted mandibular third molars and mandibular canal which is more useful than OPG imaging before the extraction to elude complications both during and after the procedure.

KEYWORDS: CBCT, OPG, Extraction, Systematic Review 


\section{INTRODUCTION:}

Wisdom teeth (often called as 8's) are the third and the final set of molars to erupt in the oral cavity during the late teens or early twenties. Historically, they are called so because they come at a more mature age that people are said to become wiser and hence nicknamed "wisdom teeth". Anthropologists accept the fact that our ancestors had larger jaw size that helped them occupy many molars up to the $5^{\text {th }}$ molars, which helped them grind on rough food like roots, leaf, nuts and meat that required more chewing power. With time, generation, and development of modern diet of softer foods along with prodigies of a modern technologies such as forks, spoons and knives, wisdom teeth slowly became nonexistent. Due to this, evolutionary biologists have classified wisdom teeth as 'vestigial organs', or body parts that have become functionless with evolution. Human jaws have become smaller throughout evolutionary history, so when wisdom teeth form, they often become impacted, or blocked by other teeth around them which do not let them erupt in the oral cavity. Also, if wisdom teeth partially erupt, food tends to get trapped in the gum that surrounds it, which in the process causes bacterial growth and simultaneously infection. They also can lead to problems such as crowding and displacement of other permanent teeth. Generally, these third molars erupt in the oral cavity at the age of 17-24 years ${ }^{1}$.

Very rarely, cyst (fluid-filled sac) formation in the soft tissue surrounding the impacted wisdom teeth can also occur, leading to bone destruction, jaw expansion ultimately damaging the surrounding teeth. Even more uncommonly, tumors can develop from the cysts causing pathological fracture of the jaws if the tumor or cysts exceeds growth.

Wisdom teeth can be removed at any age if once it has been identified to start creating problems. However, it is best to have it extracted between the age of 18 and 24. Another main factor influencing its removal from the oral cavity is when the root has developed to about two-thirds of its full size (which maybe sooner or later than 18), depending from individual to individual. After the age of 24 , the roots of wisdom teeth are fully formed leading to complex extraction procedures.
The removal of wisdom teeth at older ages may require even more complicated surgeries where the healing time could be slower with high risks of complication.

Impacted third molars occur in both maxillary and mandibular jaws. Adequate diagnosis is essential before the extraction procedure to prevent any complication. Panoramic radiography or Orthopantomograph (OPG) is the most common diagnostic aid for third molar surgeries. It is commonly used to evaluate the type of impaction, angulation, and morphology of roots. Nevertheless, the spatial relationship between the mandibular canal and impacted mandibular third molars (IMTM) cannot be assessed using panoramic radiographies ${ }^{11}$. Since it provides only a two-dimensional view, the vicinity of the tooth is not as accurate as 'Cone-beam Computed Tomography (CBCT)', which provides higher quality imaging in three-dimensional views. It has higher special resolution, and radiation from CBCT is also minimal when compared to medical computed tomography ${ }^{8}$.

IMTM are the most commonly impacted teeth in the oral cavity. According to a study, third molar impactions are occurring in about $73 \%$ of the young adults in Europe ${ }^{2}$. Its surgical removal could lead to several postoperative complications if it is not removed atraumatically. Because of its location (closer to the mandibular canal / inferior alveolar canal (IAC), it has been proven that impacted third molars are the main reason for permanent paralysis of the inferior alveolar nerve. The nerve injury ranges from 0.6 to $5.3 \%$ with permanent injury $<1 \%$ of patients ${ }^{3}$.

Although OPG offers wider-ranging coverage and easy access, detecting the meticulous proximity of the IMTM to the IAC in patients is not possible. Therefore, it is essential to extend the analysis by preferring CBCT. This systematic review aims at highlighting the benefits of CBCT by comparing its accuracy with OPG in patients who have their IMTM in close approximation with mandibular canal before surgery. The criteria such as 'presence' or 'absence' of corticalization around the IMTM in both diagnostic imaging techniques are compared and evaluated. 


\section{MATERIALS AND METHODS STUDY DESIGN:}

Systematic review of the records comparing Panoramic Imaging (OPG) and Cone Beam Computed Tomography (CBCT) for preoperative assessment of impacted mandibular third molars with mandibular canals.

\section{OBJECTIVE:}

To compare panoramic radiography with cone-beam computed tomography in the assessment of the relationship between impacted mandibular third molars and mandibular canals.

\section{SEARCH ENGINES:}

- PUBMED

- ELSEIVER SCIENCE DIRECT

- COCHRANE LIBRARY

- WILEY ONLINE LIBRARY

- Other additional sources

\section{SEARCH STRATEGY:}

All the published articles which compared the diagnostic value of Cone Beam Computed Tomography with Panoramic Radiography in the assessment of relationship between Impacted Mandibular Third Molar and Mandibular Canal preoperatively. Articles from databases such as PubMed, Elsevier Science Direct, Cochrane library, Wiley online library and additional sources were included in the review. The articles were searched to collect the relevant data using MeSH terms, "Cone-Beam Computed Tomography, Panoramic Radiography, Impacted Mandibular Third Molar and Mandibular Canal". According to the PRISMA guidelines, the $\mathrm{MeSH}$ terms were altered in each search engine, where the results produced were many or too few.

\section{INCLUSION CRITERIA:}

- Studies comparing pre-operative evaluation of IMTM with mandibular canals with OPG and CBCT.

- Studies with only clinical trials.

- Studies showing corticalization between mandibular third molar and mandibular canal.

\section{EXCLUSION CRITERIA:}

- Review articles.

- Articles proving only CBCT \& only OPG as parameters.

- Other parameters apart from CBCT and OPG.

- Other structures apart from mandibular canal with impacted mandibular third molar.

- Other teeth apart from mandibular third molars.

- Pilot studies and RCT.

- Other lesions and their surgeries.

- Post-Operative studies comparing OPG with CBCT.

- Apart from corticalization, other criteria were analyzed.

- Animal studies.

\section{RESULTS:}

A total of 383 publications based on the topic were identified. Of these, 23 were detected as duplicated and extracted. After extraction of the duplicates, the remaining articles were screened thoroughly and 20 full text articles were independently assessed. With the application of exclusion criteria, 15 studies were included in the systematic review as qualitative synthesis. Fig 1 shows the flow diagram of the above work down. 
FIG 1: FLOW DIAGRAM SHOWING THE NUMBER OF STUDIES IDENTIFIED, SCREENED, ASSESSED FOR ELIGIBILITY, EXCLUDED AND INCLUDED IN THE SYSTEMATIC REVIEW

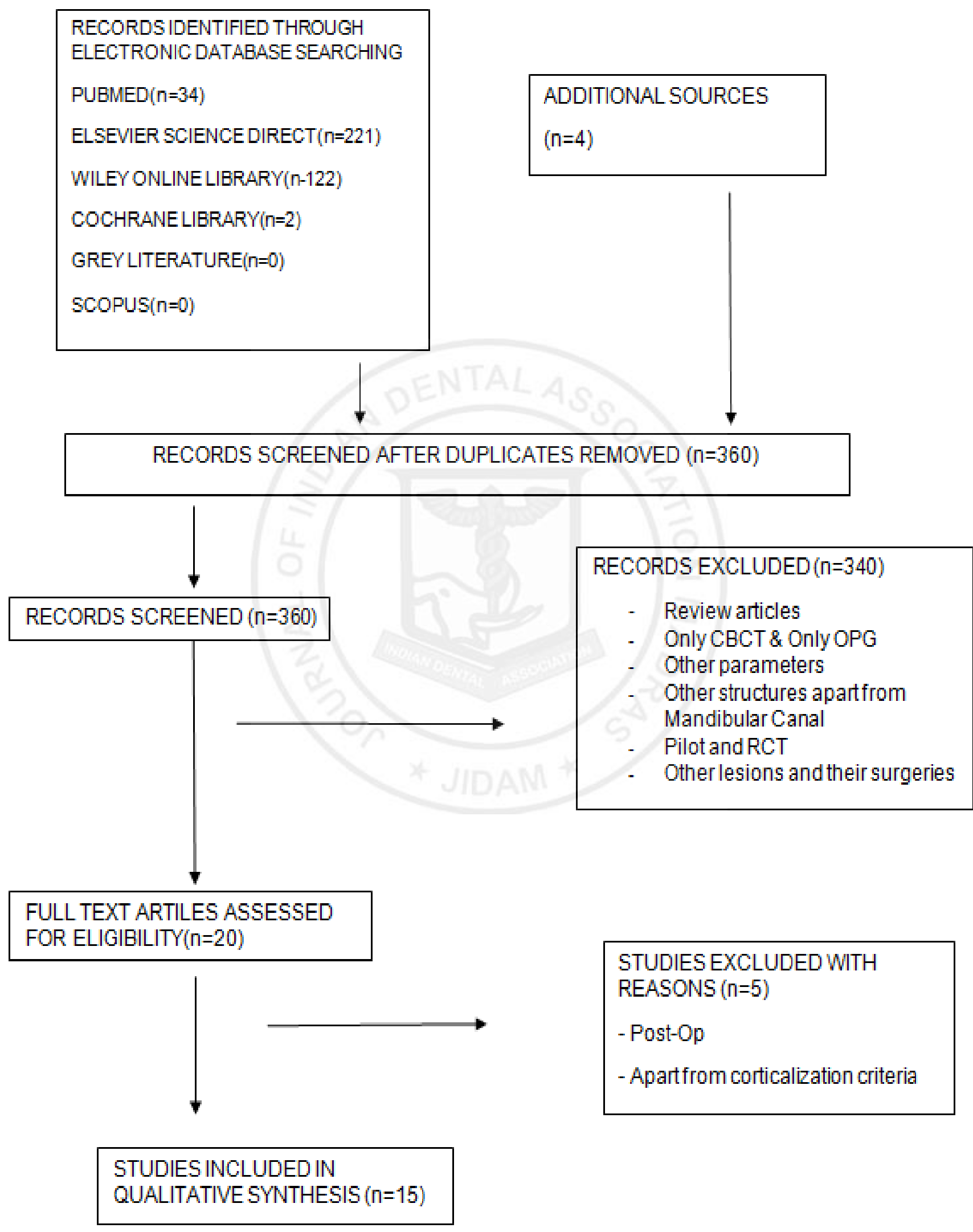


TABLE 1: CHARACTERISTICS OF INTERVENTIONS IN THE INCLUDED STUDY

\begin{tabular}{|c|c|c|c|c|}
\hline AUTHOR & YEAR & $\begin{array}{l}\text { SAMPLE } \\
\text { SIZE }\end{array}$ & $\begin{array}{l}\text { PATIENT } \\
\text { CHARACTERISTICS }\end{array}$ & $\begin{array}{l}\text { NUMBERS (CASE/ } \\
\text { CONTROL) }\end{array}$ \\
\hline $\begin{array}{l}\text { Daniela Guimardes } \\
\text { de Melo Albert et } \mathrm{al}^{4}\end{array}$ & 2006 & $\begin{array}{l}19 \text { individuals } \\
(24 \text { teeth, } 14 \text { right } \\
\text { side and } 10 \text { left } \\
\text { side) }\end{array}$ & $\begin{array}{l}9 \text { males and } 11 \\
\text { females with impacted } \\
\text { mandibular third } \\
\text { molars. }\end{array}$ & $\begin{array}{l}24 \text { teeth were } \\
\text { assessed with OPG and } \\
\text { compared with CBCT }\end{array}$ \\
\hline $\begin{array}{l}\text { Weeraya } \\
\text { Tantanapornkul et } \mathrm{al}^{5}\end{array}$ & 2007 & $\begin{array}{l}135 \text { individuals } \\
\text { (142 teeth) }\end{array}$ & $\begin{array}{l}50 \text { males and } 85 \\
\text { females with impacted } \\
\text { mandibular third } \\
\text { molars. }\end{array}$ & $\begin{array}{l}142 \text { teeth were } \\
\text { assessed with OPG and } \\
\text { compared with CBCT }\end{array}$ \\
\hline Kenji Nakamori et al ${ }^{6}$ & 2008 & $\begin{array}{l}443 \text { individuals } \\
\text { ( } 695 \text { teeth) }\end{array}$ & $\begin{array}{l}247 \text { males and } 196 \\
\text { females with impacted } \\
\text { mandibular third } \\
\text { molars. }\end{array}$ & $\begin{array}{l}576 \text { OPG and } 119 \\
\text { were compared with } \\
\text { CBCT }\end{array}$ \\
\hline H.Ghaeminia et $\mathrm{al}^{7}$ & 2009 & $\begin{array}{l}42 \text { individuals } \\
\text { ( } 56 \text { teeth) }\end{array}$ & $\begin{array}{l}20 \text { males and } 22 \\
\text { females with impacted } \\
\text { mandibular third molars. }\end{array}$ & $\begin{array}{l}56 \text { teeth were } \\
\text { assessed with OPG and } \\
\text { compared with CBCT }\end{array}$ \\
\hline $\begin{array}{l}\text { Shravan Kumar } \\
\text { Katakam et al }{ }^{8}\end{array}$ & 2012 & $\begin{array}{l}30 \text { individuals } \\
\text { (42 teeth) }\end{array}$ & $\begin{array}{l}11 \text { males and } 19 \\
\text { females with impacted } \\
\text { mandibular third molars. }\end{array}$ & $\begin{array}{l}42 \text { teeth were } \\
\text { assessed with OPG and } \\
\text { compared with CBCT }\end{array}$ \\
\hline F S Neves et $\mathrm{a}^{9}$ & 2012 & $\begin{array}{l}72 \text { individuals } \\
\text { (142 teeth) }\end{array}$ & $\begin{array}{l}28 \text { males and } 44 \\
\text { females with impacted } \\
\text { mandibular third molars. }\end{array}$ & $\begin{array}{l}142 \text { teeth were } \\
\text { assessed with OPG and } \\
\text { compared with CBCT }\end{array}$ \\
\hline $\begin{array}{l}\text { Shoaleh Shahidi et } \\
\mathrm{al}^{10}\end{array}$ & 2013 & $\begin{array}{l}96 \text { individuals } \\
\text { (132 teeth) }\end{array}$ & $\begin{array}{l}46 \text { males and } 50 \\
\text { females with impacted } \\
\text { mandibular third molars. }\end{array}$ & $\begin{array}{l}132 \text { teeth were } \\
\text { assessed with OPG and } \\
\text { compared with CBCT }\end{array}$ \\
\hline
\end{tabular}




\begin{tabular}{|c|c|c|c|c|}
\hline Ilkay Peker et al $^{11}$ & 2014 & $\begin{array}{l}191 \\
\text { individuals } \\
\text { (298 teeth) }\end{array}$ & $\begin{array}{l}68 \text { males and } 123 \\
\text { females with impacted } \\
\text { mandibular third } \\
\text { molars. }\end{array}$ & $\begin{array}{l}298 \text { teeth were } \\
\text { assessed with OPG and } \\
\text { compared with CBCT }\end{array}$ \\
\hline Saraydar-Baser $\mathrm{R}$ et al ${ }^{12}$ & 2015 & $\begin{array}{l}60 \\
\text { individuals } \\
\text { ( right side } \\
41, \text { left } \\
\text { side 19) }\end{array}$ & $\begin{array}{l}28 \text { males and } 32 \\
\text { females with impacted } \\
\text { mandibular third } \\
\text { molars. }\end{array}$ & $\begin{array}{l}60 \text { individuals ( right } \\
\text { side } 41 \text {, left side } 19 \text { ) were } \\
\text { assessed with OPG and } \\
\text { compared with CBCT }\end{array}$ \\
\hline $\begin{array}{l}\text { Larissa Rangel } \\
\text { Peixotoet } \mathrm{al}^{13}\end{array}$ & 2015 & $\begin{array}{l}50 \\
\text { individuals } \\
\text { (73 teeth) }\end{array}$ & $\begin{array}{l}26 \text { males and } 24 \\
\text { females with impacted } \\
\text { mandibular third } \\
\text { molars. }\end{array}$ & $\begin{array}{l}73 \text { teeth were } \\
\text { assessed with OPG and } \\
\text { compared with CBCT }\end{array}$ \\
\hline MahmudaAkter et al ${ }^{14}$ & 2016 & $\begin{array}{l}60 \\
\text { individuals }\end{array}$ & $\begin{array}{l}60 \text { individuals with } \\
\text { impacted mandibular } \\
\text { third molars. }\end{array}$ & $\begin{array}{l}60 \text { individuals were } \\
\text { assessed with OPG and } \\
\text { compared with CBCT }\end{array}$ \\
\hline SonaliGhai et al ${ }^{15}$ & 2017 & $\begin{array}{l}60 \\
\text { individuals } \\
\text { (53 teeth) }\end{array}$ & $\begin{array}{l}60 \text { individuals with } \\
\text { impacted mandibular } \\
\text { third molars. }\end{array}$ & $\begin{array}{l}53 \text { teeth were } \\
\text { assessed with OPG and } \\
\text { compared with CBCT }\end{array}$ \\
\hline $\begin{array}{l}\text { Kate L. Winstanley et } \\
\mathrm{al}^{16}\end{array}$ & 2017 & $\begin{array}{l}55 \\
\text { individuals } \\
\text { (100 teeth) }\end{array}$ & $\begin{array}{l}15 \text { males and } 40 \\
\text { females with impacted } \\
\text { mandibular third } \\
\text { molars. }\end{array}$ & $\begin{array}{l}10 \text { teeth were } \\
\text { assessed with OPG and } \\
\text { compared with CBCT }\end{array}$ \\
\hline $\begin{array}{l}\text { Darshana S Nayak et } \\
\mathrm{al}^{17}\end{array}$ & 2018 & $\begin{array}{l}24 \\
\text { individuals } \\
\text { (40 teeth) }\end{array}$ & $\begin{array}{l}5 \text { males and } 19 \\
\text { females with impacted } \\
\text { mandibular third } \\
\text { molars. }\end{array}$ & $\begin{array}{l}40 \text { teeth were } \\
\text { assessed with OPG and } \\
\text { compared with CBCT }\end{array}$ \\
\hline $\begin{array}{l}\text { Vinay Kumar Reddy } \\
\text { Kundoor et al }^{18}\end{array}$ & 2018 & $\begin{array}{l}40 \\
\text { individuals } \\
(60 \text { teeth) }\end{array}$ & $\begin{array}{l}16 \text { males and } 24 \text { females } \\
\text { with impacted } \\
\text { mandibular third molars. }\end{array}$ & $\begin{array}{l}60 \text { teeth were assessed with } \\
\text { OPG and compared with } \\
\text { CBCT }\end{array}$ \\
\hline
\end{tabular}

TABLE 1 shows the characteristics of intervention in the included studies. In all the 15 studies, the accuracy of CBCT images were compared with OPG images in a controlled group which differed in sample size, gender and number of impacted teeth diagnosed. Only the OPG which showed IMTM having close approximation with mandibular canal were further preferred for taking up CBCT diagnosis. 
TABLE 2: OUTCOME DATA AS REPORTED IN INCLUDED STUDIES

\begin{tabular}{|c|c|c|c|c|}
\hline AUTHOR & YEAR & EFFECT MEASURE & RESULTS & P VALUES \\
\hline $\begin{array}{l}\text { Daniela } \\
\text { Guimardes de } \\
\text { Melo Albert et } \mathrm{al}^{4}\end{array}$ & 2006 & $\begin{array}{l}\text { Darkening of the root, } \\
\text { narrowing and deviation of the } \\
\text { canal, narrowing and bifid } \\
\text { apexes from OPG were } \\
\text { compared with CBCT and } \\
\text { evaluated. }\end{array}$ & $\begin{array}{l}\text { Darkening of roots } \\
(92.1 \%) \text { was majorly seen } \\
\text { in CBCT along with } \\
\text { narrowing of mandibular } \\
\text { canal }(12.9 \%) \text { and apex. }\end{array}$ & Not Mentioned \\
\hline $\begin{array}{l}\text { Weeraya } \\
\text { Tantanapornkul et } \\
\mathrm{al}^{5}\end{array}$ & 2007 & $\begin{array}{l}\text { Interruption of the mandibular } \\
\text { canal wall, darkening of the } \\
\text { root, diversion of the } \\
\text { mandibular canal, and } \\
\text { narrowing of the root in } \\
\text { Panoramic radiography was } \\
\text { evaluated using logistic } \\
\text { regression. The sensitivity and } \\
\text { specificity between OPG and } \\
\text { CBCT was also calculated. }\end{array}$ & $\begin{array}{l}\text { The interruption of the } \\
\text { mandibular canal was } \\
\text { proved as diagnostic } \\
\text { criterion of OPG image to } \\
\text { predict the neurovascular } \\
\text { bundle during extraction. } \\
\text { Also the a) sensitivity of } \\
\text { CBCT was } 93 \% \text { and b) } \\
\text { specificity } 77 \% \text { which } \\
\text { was far superior to that of } \\
\text { OPG. }\end{array}$ & $\begin{array}{l}\text { a)p }<0.05 \\
\text { b)p }<0.05\end{array}$ \\
\hline $\begin{array}{ll}\text { Kenji } & \text { Nakamori } \\
\text { et al } & \end{array}$ & 2008 & $\begin{array}{l}\text { Darkening, deflection and } \\
\text { narrowing of the root, } \\
\text { narrowing and diversion of the } \\
\text { canal and interruption of the } \\
\text { white line from OPG were } \\
\text { compared with CBCT for } \\
\text { presence and absence of } \\
\text { cortication. Chi- squared and } \\
\text { Logistic regression was carried } \\
\text { out. }\end{array}$ & $\begin{array}{l}\text { There was significance for } \\
\text { a) darkness of the root, b) } \\
\text { diversion of the canal and } \\
\text { c) narrowing of the canal. }\end{array}$ & $\begin{array}{l}\text { a) } p=0.049 \\
\text { b) } p=0.019 \\
\text { c) } p=0.003\end{array}$ \\
\hline $\begin{array}{l}\text { H.Ghaeminia et al } \\
7\end{array}$ & 2009 & $\begin{array}{l}\text { Patients with close relationship } \\
\text { between IMTM and } \\
\text { Mandibular canal in OPG were } \\
\text { asked to take CBCT. } \\
\text { Darkening of the root, } \\
\text { interruption of white line of } \\
\text { the mandibular canal, } \\
\text { diversion and narrowing of the } \\
\text { canal were evaluated with Chi- } \\
\text { Squared }\left(\mathrm{X}^{2}\right) \text { test. Less than } \\
0.05 \text { were considered }\end{array}$ & $\begin{array}{l}\text { Only darkening of the root } \\
\text { showed significant } \\
\text { association with Inferior } \\
\text { Alveolar Nerve exposure } \\
\text { and Odds ratio (0.204). }\end{array}$ & $\mathrm{p}=0.007$ \\
\hline
\end{tabular}




\begin{tabular}{|c|c|c|c|c|}
\hline & & $\begin{array}{l}\text { statistically significant. } \\
\text { Logistic regression was then } \\
\text { carried out. }\end{array}$ & & \\
\hline $\begin{array}{l}\text { Shravan Kumar } \\
\text { Katakam et al }^{8}\end{array}$ & 2012 & $\begin{array}{l}\text { Darkening and deflection of } \\
\text { roots, narrowing of apex and } \\
\text { the canal, deviation of canal, } \\
\text { deflection of white line and } \\
\text { bifid apexes from OPG were } \\
\text { evaluated and compared with } \\
\text { CBCT. Chi-squared and Z test } \\
\text { was performed. }\end{array}$ & $\begin{array}{l}\text { Z-value }>1.5 \text { in darkening } \\
\text { of roots (1.98), deflection } \\
\text { of root }(2.00), \mathrm{z} \text {-value }=0 \\
\text { in narrowing of canal and } \\
\text { dark, bifid apexes. Also it } \\
\text { showed significant p- } \\
\text { value in all the } \\
\text { radiographic signs except } \\
\text { narrowing of mandibular } \\
\text { canal, dark and bifid } \\
\text { apexes. }\end{array}$ & $\mathrm{p}<0.05$ \\
\hline F S Neves et al ${ }^{9}$ & 2012 & $\begin{array}{l}\text { Comparing the Panoramic } \\
\text { radiography and CBCT } \\
\text { findings according to the } \\
\text { relationship between the roots } \\
\text { of the third molars and the } \\
\text { mandibular canal using } \\
\text { Fisher's exact test, with a } \\
\text { significance level of } \mathrm{p}<0.05 \text {. }\end{array}$ & $\begin{array}{l}\text { a)Darkening of roots and } \\
\text { b) interruption in white } \\
\text { line, as both isolated } \\
\text { findings and c)in } \\
\text { association with each } \\
\text { other revealed a } \\
\text { statistically significant } \\
\text { association with the } \\
\text { absence of corticalization } \\
\text { between the mandibular } \\
\text { third molar and the } \\
\text { mandibular canal in } \\
\text { CBCT images }\end{array}$ & $\begin{array}{l}\text { a) } p=0.0001 \\
\text { b) } p=0.0006 \\
\text { c) } p=0.002\end{array}$ \\
\hline $\begin{array}{l}\text { Shoaleh Shahidi } \\
\text { et al }^{10}\end{array}$ & 2013 & $\begin{array}{l}\text { The presence or absence of } \\
\text { direct contact on the } \\
\text { Panoramic radiographs was } \\
\text { evaluated by the following } \\
\text { four features, to find out the } \\
\text { close contact between the } \\
\text { tooth root and the mandibular } \\
\text { canal: (a) interruption of the } \\
\text { mandibular canal wall, (b) } \\
\text { darkening of the root,(c) } \\
\text { diversion of the mandibular } \\
\text { canal, and(d) root dilacerations } \\
\text { using logistic regression }\end{array}$ & $\begin{array}{l}\text { Interruption of the cortical } \\
\text { lines on a panoramic } \\
\text { image raised the risk of } \\
\text { root and canal contact on } \\
\text { CBCT images (odds } \\
\text { ratio=5.75) and showed } \\
\text { the highest sensitivity } \\
\text { among the four signs of } \\
\text { association. However } \\
\text { darkening of roots, } \\
\text { diversion of mandibular } \\
\text { canal and root } \\
\text { dilacerations also } \\
\text { increased the risk of } \\
\text { association between the } \\
\text { tooth and the canal in } \\
\text { CBCT. }\end{array}$ & Not Mentioned \\
\hline Ilkay Peker et al & 2014 & Darkening of the roots, & There was a significant & $\mathrm{p}<0.05$ \\
\hline
\end{tabular}




\begin{tabular}{|c|c|c|c|c|}
\hline 11 & & $\begin{array}{l}\text { diversion of the mandibular } \\
\text { canal, narrowing of the } \\
\text { mandibular canal and } \\
\text { interruption of the white line } \\
\text { on Panoramic radiography } \\
\text { were compared with CBCT } \\
\text { and evaluated by chi-square } \\
\text { and Fisher's exact tests, with a } \\
\text { significance level of } \mathrm{p}<0.05 \text {. }\end{array}$ & $\begin{array}{l}\text { association between } \\
\text { darkening of the roots and } \\
\text { interruption of the white } \\
\text { line on Panoramic images } \\
\text { and the presence of } \\
\text { contact between the } \\
\text { IMTM and the Inferior } \\
\text { Alveolar Canal (IAC) on } \\
\text { CBCT images }(\mathrm{p}<0.05) \text {. }\end{array}$ & \\
\hline $\begin{array}{l}\text { Saraydar-Baser } \mathrm{R} \\
\text { et al } 12\end{array}$ & 2015 & $\begin{array}{l}\text { Darkening and contraction of } \\
\text { the tooth root, suspension of } \\
\text { the white cortical line of the } \\
\text { IAC, deviation or bending of } \\
\text { the IAC, Dark and bifid root } \\
\text { apex, island-shaped apex, } \\
\text { bending of the root and } \\
\text { contraction of the IAC from } \\
\text { OPG were compared with } \\
\text { CBCT for surgical outcomes. } \\
\text { Chi-squared, Fisher's tests } \\
\text { were done along with } \\
\text { sensitivity and specificity. }\end{array}$ & $\begin{array}{l}\text { a) Deflection and curvature } \\
\text { of the root, a) dark bifid } \\
\text { root apex near the nerve, } \\
\text { and c) an island-shaped } \\
\text { apex in OPG showed a } \\
\text { significant agreement with } \\
\text { the results of surgical } \\
\text { findings respectively. } \\
\text { d)CBCT results with the } \\
\text { surgical results was } \\
\text { evaluated at a } \\
\text { Kappa of } 0.813 \text {, which is } \\
\text { important at (p = } 0.001 \text { ). } \\
\text { The sensitivity of CBCT } \\
\text { was found to be } 100 \% \text { and } \\
\text { specificity } 94 \% \text { in this } \\
\text { study. }\end{array}$ & $\begin{array}{l}\text { a)p }=0.022 \\
\text { b) } p=0.027 \\
\text { c) } p=0.007 \\
\text { d) } p=0.001\end{array}$ \\
\hline $\begin{array}{l}\text { Larissa Rangel } \\
\text { Peixotoet al }{ }^{13}\end{array}$ & 2015 & $\begin{array}{l}\text { Darkening, deflection, } \\
\text { superimposition and narrowing } \\
\text { of the root, diversion of the } \\
\text { canal, interruption of the } \\
\text { cortex and bifid apexes from } \\
\text { OPG were compared with } \\
\text { CBCT findings. True and } \\
\text { False positive responses were } \\
\text { calculated. }\end{array}$ & $\begin{array}{l}\text { The "True Positive" } \\
\text { response for darkening of } \\
\text { the roots and interruption } \\
\text { of the cortex with the } \\
\text { canal was } 9 \text {, } \\
\text { superimposition of the } \\
\text { root showed } 5 \text { whereas } \\
\text { diversion of the canal } \\
\text { showed } 2 \text { and narrowing } \\
\text { of the root a) The P value } \\
\text { significance between the } \\
\text { three modalities were also } \\
\text { found (original, inverted }\end{array}$ & a) $p=0.981$ \\
\hline
\end{tabular}




\begin{tabular}{|c|c|c|c|c|}
\hline & & & and edge enhanced). & \\
\hline $\begin{array}{l}\text { Mahmuda Akter } \\
\text { et al }^{14}\end{array}$ & 2016 & $\begin{array}{l}\text { Darkening of roots and } \\
\text { narrowing of mandibular canal } \\
\text { from OPG to evaluate which } \\
\text { type of impaction had close } \\
\text { relationship with mandibular } \\
\text { canal. This was later compared } \\
\text { with CBCT findings. }\end{array}$ & $\begin{array}{l}\text { The results show that } \\
\text { darkening of roots showed } \\
\text { majority of them in buccal } \\
\text { position and concluding } \\
\text { that horizontally impacted } \\
\text { mandibular third molars } \\
\text { have intimate relation } \\
\text { with inferior alveolar } \\
\text { canal. }\end{array}$ & Not Mentioned \\
\hline $\begin{array}{l}\text { Sonali Ghai et al } \\
15\end{array}$ & 2017 & $\begin{array}{l}\text { Darkening of the root, } \\
\text { deviation and narrowing of the } \\
\text { canal, narrowing and } \\
\text { deflection of the root, } \\
\text { interruption of the white line, } \\
\text { dark and bifid root apexes } \\
\text { from OPG were compared } \\
\text { with CBCT with the presence } \\
\text { and absence of corticalization. }\end{array}$ & $\begin{array}{l}\text { Darkening of the root } \\
\text { (DR) being the most } \\
\text { common } 22.64 \% \text { while } \\
\text { Interruption of White } \\
\text { Lines (IWL)being the } \\
\text { second most common } \\
18.86 \% \text { panoramic } \\
\text { radiographic finding, } \\
\text { when compared with } \\
\text { CBCT, absence of } \\
\text { corticalization was most } \\
\text { commonly associated with } \\
\text { DR and IWL, seen in } 70 \% \\
\text { of cases. }\end{array}$ & $\mathrm{p}<0.05$ \\
\hline $\begin{array}{l}\text { Kate } \\
\text { Winstanley et } \mathrm{al}^{16}\end{array}$ & 2017 & $\begin{array}{l}\text { Interruption of the white line } \\
\text { of the canal, tooth touching } \\
\text { white line of the canal, } \\
\text { darkening, narrowing and } \\
\text { deflection of the roots, } \\
\text { narrowing and deflection of } \\
\text { the canal from OPG were } \\
\text { compared with CBCT. Chi- } \\
\text { squared and Fisher's exact } \\
\text { tests were carried out with } \\
\text { significance set at } \mathrm{P}<.05 \text {. }\end{array}$ & $\begin{array}{l}\text { a) Darkening of the roots } \\
(\mathrm{N}=22) \text { and } \mathrm{b}) \\
\text { interruption of the white } \\
\text { line }(\mathrm{N}=47) \text { were found } \\
\text { to be significant. }\end{array}$ & $\begin{array}{l}\text { a) } p=0.041 \\
\text { b) } p=0.024\end{array}$ \\
\hline $\begin{array}{ll}\text { Darshana } & \mathrm{S} \\
\text { Nayak et al }^{17} & \end{array}$ & 2018 & $\begin{array}{l}\text { Darkening of roots, deflection } \\
\text { of the apex, dark and bifid } \\
\text { apexes, deviation and } \\
\text { narrowing of the canal from } \\
\text { OPG was compared with } \\
\text { CBCT. The CBCT images } \\
\text { were also evaluated in axial, } \\
\text { sagittal, and coronal planes to } \\
\text { determine true relationship } \\
\text { between the tooth and the }\end{array}$ & $\begin{array}{l}\text { Darkening of the apex } \\
(\mathrm{n}=13,56.5 \%) \text { and } \\
\text { narrowing of the canal } \\
(\mathrm{n}=4,17.4 \%) \text { were the } \\
\text { signs most frequently } \\
\text { associated with a true } \\
\text { relationship on CBCT. } \mathrm{P} \\
\text { value significance was }\end{array}$ & $\begin{array}{l}\text { a)p }<0.001 \\
\text { b) } p=0.001 \\
\text { c) } p<0.001\end{array}$ \\
\hline
\end{tabular}




\begin{tabular}{|c|c|c|c|c|c|}
\hline & & & $\begin{array}{l}\text { canal in which radiographic } \\
\text { signs represent a true } \\
\text { relationship. } \\
\text { analysis was carried out using } \\
\text { Chi-square test of significance } \\
\mathrm{P} \text { value }<0.05 \text {. }\end{array}$ & $\begin{array}{l}\text { calculated in three } \\
\text { sections, namely, a) the } \\
\text { coronal section, b) sagittal } \\
\text { and c) axial section. }\end{array}$ & \\
\hline $\begin{array}{l}\text { Vinay } \\
\text { Reddy } \\
\text { et al }{ }^{18}\end{array}$ & $\begin{array}{r}\text { Kumar } \\
\text { Kundoor }\end{array}$ & 2018 & $\begin{array}{l}\text { The association of Panoramic } \\
\text { radiography and CBCT } \\
\text { findings were analyzed using } \\
\text { Chi square test and Fisher's } \\
\text { exact test for darkening of the } \\
\text { root, interruption of the } \\
\text { mandibular canal, and contact } \\
\text { of canal to root. }\end{array}$ & $\begin{array}{l}\text { a) Panoramic radiographic } \\
\text { signs were statistically } \\
\text { associated with the } \\
\text { buccolingual position of } \\
\text { the mandibular canal } \\
\text { relative to the impacted } \\
\text { mandibular third molar on } \\
\text { CBCT. Contact with the } \\
\text { canal was more frequently } \\
\text { observed when the } \\
\text { interruption of the } \\
\text { mandibular canal and } \\
\text { darkening was seen on the } \\
\text { panoramic radiographs. }\end{array}$ & a)p $<0.01$ \\
\hline
\end{tabular}

TABLE 2 shows the outcome data of accuracy and reliability of CBCT diagnosis prior to the IMTM removal to prevent post-surgical complications. All the 15 studies discussed had the same criteria (corticalisation) assessed.

TABLE 3: TECHNICAL CBCT DATA AND FURTHER INFORMATION FROM THE INCLUDED STUDIES

\begin{tabular}{|l|l|l|l|l|}
\hline AUTHOR & CBCT SYSTEM & $\begin{array}{l}\text { SCAN } \\
\text { SETTING }\end{array}$ & $\begin{array}{l}\text { IMAGE } \\
\text { RESOLUTION }\end{array}$ & $\begin{array}{l}\text { OTHER } \\
\text { INFORMATION }\end{array}$ \\
\hline $\begin{array}{l}\text { Daniela Guimardes de } \\
\text { Melo Albert et al }{ }^{4}\end{array}$ & $\begin{array}{l}\text { CommCat 752 } \\
\text { (Imaging Sciences } \\
\text { Corporation) }\end{array}$ & $\begin{array}{l}\text { Information } \\
\text { not provided }\end{array}$ & $12.7 \times 30.5$ size & $\begin{array}{l}\text { Information not } \\
\text { provided }\end{array}$ \\
\hline $\begin{array}{l}\text { Weeraya } \\
\text { Tantanapornkul et al }\end{array}$ & $\begin{array}{l}\text { 3DX multi image } \\
\text { micro CT }\end{array}$ & $\begin{array}{l}80 \mathrm{Kv}, 2 \mathrm{~mA} \\
\text { and } 17 \\
\text { seconds }\end{array}$ & $\begin{array}{l}\text { height, 320 } \\
\text { voxels diameter } \\
\text { and isotropic } \\
\text { cubic voxels } \\
\text { with sides } \\
0.12 \mathrm{~mm}\end{array}$ & $\begin{array}{l}\text { Information not } \\
\text { provided }\end{array}$ \\
\hline Kenji Nakamori et al ${ }^{6}$ & $\begin{array}{l}\text { Information not } \\
\text { provided }\end{array}$ & $\begin{array}{l}\text { Information } \\
\text { not provided }\end{array}$ & $\begin{array}{l}\text { Information not } \\
\text { provided }\end{array}$ & $\begin{array}{l}\text { Information not } \\
\text { provided }\end{array}$ \\
\hline
\end{tabular}




\begin{tabular}{|c|c|c|c|c|}
\hline  & $\begin{array}{l}\text { Classic i-CAT } \\
\text { CBCT unit } \\
\text { (Imaging Sciences } \\
\text { International) }\end{array}$ & $\begin{array}{l}120 \mathrm{kVp}, 3-8 \\
\mathrm{~mA} \text { and } 20 \\
\text { seconds }\end{array}$ & $\begin{array}{l}\text { Field of view } \\
6 \mathrm{~cm} \text { and voxel } \\
\text { size } 0.25 \mathrm{~mm}\end{array}$ & $\begin{array}{l}\text { Information not } \\
\text { provided }\end{array}$ \\
\hline $\begin{array}{l}\text { Shravan Kumar } \\
\text { Katakam et al }^{8}\end{array}$ & $\begin{array}{l}\text { Siemens volume } \\
\text { access multislice } \\
\text { spiral CT }\end{array}$ & $\begin{array}{l}120 \mathrm{KVP}, \\
90 \mathrm{~mA}\end{array}$ & $\begin{array}{l}0.15 \mathrm{~mm} \text { slice } \\
\text { thickness }\end{array}$ & $\begin{array}{l}\text { Images } \\
\text { reconstructed in } \\
\text { sharp kernel H60S } \\
\text { in dental window }\end{array}$ \\
\hline F S Neves et al $^{9}$ & $\begin{array}{l}\text { Classic i-CAT } \\
\text { CBCT unit } \\
\text { (Imaging Sciences } \\
\text { International) }\end{array}$ & $120 \mathrm{kVp} / 8 \mathrm{~mA}$ & $\begin{array}{l}0.25 \mathrm{~mm} \text { voxel } \\
\text { size and field } \\
\text { view of } 8 \mathrm{~cm}\end{array}$ & $\begin{array}{l}\text { Information not } \\
\text { provided }\end{array}$ \\
\hline Shoaleh Shahidi et al & Kodak 9000 & $\begin{array}{l}90 \mathrm{k} \nabla \mathrm{p}, \\
6 \mathrm{~mA} \text {, and } 10 \\
\text { seconds }\end{array}$ & $\begin{array}{l}\text { Intormation not } \\
\text { provided }\end{array}$ & $\begin{array}{l}\text { Intormation not } \\
\text { provided }\end{array}$ \\
\hline Tlkay Peker et al & $\begin{array}{l}\text { Promax SD unit } \\
\text { (PlanmecaOy, } \\
\text { Helsinki, Finland) }\end{array}$ & $\begin{array}{l}84 \mathrm{kVp}, 9-14 \\
\mathrm{Ma}, 6 \text { seconds }\end{array}$ & $\begin{array}{l}0.16 \mathrm{~mm} \text { voxel } \\
\text { size and a field } \\
\text { of view of } 8 \mathrm{~cm}\end{array}$ & $\begin{array}{l}\text { Intormation not } \\
\text { provided }\end{array}$ \\
\hline Saraydar-Baser $\mathrm{K}$ et al ${ }^{12}$ & PromaxPlanmeca & $\begin{array}{l}\text { 8णKvp, } \\
12 \mathrm{~mA} \text { for } 17 \\
\text { seconds }\end{array}$ & $\begin{array}{l}\text { Intormation not } \\
\text { provided }\end{array}$ & $\begin{array}{l}\text { Intormation not } \\
\text { provided }\end{array}$ \\
\hline $\begin{array}{l}\text { Larissa Rangel Peixoto } \\
\text { et } \mathrm{al}^{13}\end{array}$ & Siemens AG & $\begin{array}{l}110 \mathrm{kVp} \text { and } \\
1.60-8.21 \mathrm{~mA}\end{array}$ & $\begin{array}{l}\text { high-resolution } \\
\text { gray-scale SMM } \\
\text { Series monitor } \\
\text { was used }\end{array}$ & $\begin{array}{l}\text { Intormation not } \\
\text { provided }\end{array}$ \\
\hline Mahmuda Akter et al ${ }^{14}$ & $\begin{array}{l}\text { Information not } \\
\text { provided }\end{array}$ & $\begin{array}{l}\text { Information } \\
\text { not provided }\end{array}$ & $\begin{array}{l}\text { Information not } \\
\text { provided }\end{array}$ & $\begin{array}{l}\text { Information not } \\
\text { provided }\end{array}$ \\
\hline Sonali Ghai et al ${ }^{15}$ & $\begin{array}{l}\text { ORTHOPHOS XG } \\
\text { 3D imaging system }\end{array}$ & $\begin{array}{l}60-90 \mathrm{kVp} \\
9-12 \mathrm{~mA}\end{array}$ & $\begin{array}{l}100 \mathrm{~lm} \text { Voxel } \\
\text { size and } 50 * 55 \\
\mathrm{~mm}\end{array}$ & $\begin{array}{l}\text { Information not } \\
\text { provided }\end{array}$ \\
\hline $\begin{array}{l}\text { Kate L. Winstanley et } \\
\text { al }^{16}\end{array}$ & $\begin{array}{l}\text { 1- CAI Next } \\
\text { Generation } \\
\text { imaging system } \\
\text { (Imaging Sciences } \\
\text { International) }\end{array}$ & $\begin{array}{l}\mathrm{T} 20 \mathrm{kV}, \mathrm{J} \\
\mathrm{mA}, 14.7 \text { or } \\
26.9 \text { seconds }\end{array}$ & $\begin{array}{l}\text { Intormation not } \\
\text { provided }\end{array}$ & $\begin{array}{l}\text { Intormation not } \\
\text { provided }\end{array}$ \\
\hline $\begin{array}{l}\text { Darshana S Nayak et } \\
\text { al }^{13,17}\end{array}$ & $\begin{array}{l}\text { Planmeca } \\
\text { Promax3D }\end{array}$ & $\begin{array}{l}96 \mathrm{Kvp} \text { and } \\
\text { current } 10 \mathrm{~mA}\end{array}$ & $\begin{array}{l}\text { Size thickness } \\
1 \mathrm{~mm} \text { in axial, } \\
\text { coronal and } \\
\text { sagittal view }\end{array}$ & $\begin{array}{l}\text { Information not } \\
\text { provided }\end{array}$ \\
\hline
\end{tabular}




\begin{tabular}{|l|l|l|l|l|}
\hline $\begin{array}{l}\text { Vinay Kumar Reddy } \\
\text { Kundoor et a }{ }^{18}\end{array}$ & $\begin{array}{l}\text { New Tom Cone } \\
\text { Beam 3D imaging }\end{array}$ & $\begin{array}{l}120 \mathrm{kVp}, \\
8 \mathrm{~mA}\end{array}$ & $\begin{array}{l}0.2 \mathrm{~mm} \text { voxel } \\
\text { size and field } \\
\text { view of } 8 \mathrm{~cm}\end{array}$ & $\begin{array}{l}\text { Information not } \\
\text { provided }\end{array}$ \\
\hline
\end{tabular}

TABLE 3 shows the CBCT data and other information from included studies

\section{DISCUSSION:}

This systematic review is based on 15 clinical studies to find the effects and reliability of CBCT over OPG. Many other studies that also compared the same or proved the effectiveness were not included due to the reasons already mentioned in Fig 1 (exclusion criteria). The studies in which the criteria of 'Corticalisation' was used to assess the relationship between IMTM and the mandibular canal was considered to be the main factor for including them in this systematic review. However, the results of these studies were almost similar stating that CBCT is the most accurate method for diagnosis than OPG before the removal of IMTM to prevent IAC injury and post-operative complications.

There is evidence which states that the presence of darkening of roots and interruption of the white line in OPG, as both separate findings and in association with each other is effective in influencing the risk relationship between IMTM and mandibular canal, which further certainly requires a 3D evaluation (CBCT) before surgery $3,6,9,10,13,15,16$. The darkening of the root describes an increased radiolucent feature with the impingement of the canal over the third molar area and the strongest sign for IAN exposure and post-operative paresthesia ${ }^{19}$. It is also proven that there could be marked thinning or perforation of the cortical plates $^{13}$. However, diversion and narrowing of the mandibular canal and root dilacerations also increased the risk of association between the tooth and the canal in $\mathrm{CBCT}^{4,10,14}$. There was also a noteworthy difference in the number of roots of IMTM and the position (buccolingual) of the canal detected on OPG versus CBCT imaging, proving that OPG diagnosis solitarily is not sufficient ${ }^{11,18}$. Darkening of the roots along with the narrowing of apices was also one of the common OPG findings which instigated the need for CBCT confirmation ${ }^{8,17}$. The sensitivity and specificity of CBCT was found to be far superior compared to OPG in various studies ${ }^{5,12}$.
According to the authors, the 3D examination of CBCT should be carried out when darkening of roots, narrowing of the mandibular canal, and interruption of white line is observed on $\mathrm{OPG}^{9-18}$. However, the predictability in judging the nerve lesion during the procedure and post-operative complication, with the consideration of the socioeconomic status, and the high cost, the use of OPG pre-operatively before third molar surgery is clearly justified ${ }^{18}$. CBCT depicts nearness of the IMTM to neighboring anatomical structures precisely which helps in creating good surgical plan and predicting post-operative complications which is of extreme importance in the period of medico-legal consumerism ${ }^{10}$. Nonetheless, OPG acts as a valuable guide in depicting mandibular third molars when used in stepwise logistic manner ${ }^{8}$.

\section{LIMITATIONS:}

Although the use of CBCT for the diagnosis of IMTM prior to its surgical removal is $100 \%$ accurate and effective, the cost factor being its major drawback would result in negligence in the use of it.

\section{CONCLUSION:}

With the above-discussed articles in which the significance of CBCT was proven statistically more essential that OPG method of diagnosis, we could conclude that $\mathrm{CBCT}$ evaluation in determining the relationship between impacted mandibular third molar and mandibular canal is more useful than OPG imaging before the extraction of the tooth as it majorly avoids complications both during and after the procedures.

\section{FINANCIALSUPPORTANDSPONSORSHIP:}

\section{Nil}




\section{CONFLICTS OF INTEREST:}

There are no conflicts of interest.

\section{REFERENCES:}

1. Santosh P. Impacted mandibular third molars: Review of literature and a proposal of a combined clinical and radiological classification. Ann Med Health Sciences Research. 2015;5(4):229-234.

2. Spiotto M, Juodzbalys G, Daugela P. Mandibular Third Molar Impaction: Review ofLiterature and a Proposal of a Classification. J Oral Maxillofac Resear. 2013;4(2):1-12.

3. Tantanapornkul W, Okochi K, Bhakdinaronk A, Ohbayashi N, Kurabayashi T. Correlation of darkening of impacted mandibular third molar root on digital panoramic images with cone beam computed tomography findings. Dento maxfacial Radiol. 2009;38(1):11-6.

4. DeMelo Albert DG, Gomes AC, do EgitoVasconcelos BC, e Silva ED, Holanda GZ. Comparison of orthopantomographs and conventional tomography images for assessing the relationship between impacted lower third molars and the mandibular canal. J oral maxillofacial surg. 2006;64(7):1030-7.

5. Tantanapornkul W, Mavin D, Prapaiphittayakun J, Phipatboonyarat N, Julphantong W. Accuracy of panoramic radiograph in assessment of the relationship between mandibular canal and impacted third molars. Open dent J. 2016;10:322-6.

6. Nakamori $\mathrm{K}$ et al. Clinical assessment of the relationship between the third molar and the inferior alveolar canal using panoramic images and computed tomography. $\mathrm{J}$ oral maxillofac surg. 2008;66(11):2308- 13 .

7. Ghaeminia H, Meijer GJ, Soehardi A, Borstlap WA, Mulder J, Bergé SJ. Position of the impacted third molar in relation to the mandibular canal. Diagnostic accuracy of cone beam computed tomography compared with panoramic radiography. Int $\mathrm{J}$ oral maxillofac surg. 2009;38(9):964-71.

8. Katakam SK, Shankar U, Thakur D, Reddy TP, Hari KR, Janga D. Comparison of orthopantomography and computed tomography image for assessing the relationship between impacted mandibular third molar and mandibular canal. J Contemp Dent Pract. 2012;1(13):6-10.

9. Neves FS, Souza TC, Almeida SM, HaiterNeto F, Freitas DQ, Bóscolo FN. Correlation of panoramic radiography and cone beam CT findings in the assessment of the relationship between impacted mandibular third molars and the mandibular canal. Dent maxillofal radiol. 2012;41(7):553-7.

10. Shahidi S, Zamiri B, Bronoosh P. Comparison of panoramic radiography with cone beam $\mathrm{CT}$ in predicting the relationship of the mandibular third molar roots to the alveolar canal. Imag scienc dent. 2013;43(2):105-9.

11. Peker I, Sarikir C, Alkurt MT, Zor ZF. Panoramic radiography and cone-beam computedtomography findings inpreoperative examination of impacted mandibular third molars. BMC oral healt. 2014;14(1):71-5.

12. Saraydar-Baser $\mathrm{R}$ et al. Comparison of the diagnostic value of CBCT and Digital Panoramic Radiography with surgical findings to determine the proximity of an impacted third mandibular molar to the inferior alveolar nerve canal. J med life. 2015;8(Spec Iss 3):83.

13. Peixoto LR, Gonzaga AK, Melo SL, dos AnjosPontual ML, dos AnjosPontual A, de Melo DP. The effect of two enhancement tools on the assessment of the relationship between third molars and the inferior alveolar canal. J Cran Maxillofac Surg. 2015;43(5):637-42.

14. Akter M, Rahman QB, Uddin MW, Kundu GC, Banik S, Imon AA. Pre-operative assessment of impacted mandibular third molar and inferior alveolar canal using orthopantomograhpy and cone beam computed tomography. Bangabandhu 
She Muj Med Univ J. 2016;9(4):220-2.

15. Ghai S, Choudhury S. Role of Panoramic Imaging and Cone Beam CT for Assessment of Inferior Alveolar Nerve Exposure and Subsequent Paresthesia Following Removal of Impacted Mandibular Third Molar. J maxillofac oral surg. 2018;17(2):242-7.

16. Winstanley KL et al. Inferior alveolar nerve injury: Correlation between indicators of risk on panoramic radiographs and the incidence of tooth and mandibular canal contact on cone-beam computed tomography scans in a Western Australian population. J invest clin dent. 2018:e12323.

17. Nayak DS, Raghavan SA, Birur P, Gurudath S, Keerthi G. Determination of Proximity of Mandibular Third Molar to Mandibular Canal Using Panoramic Radiography and Cone-beam Computed Tomography. J Ind Acad Oral Med Radiol. 2017;29(4):273.

18. Kundoor VK, Maloth KN, Patimeedi A, Thakur M, Nomula R, Sunitha K. Objectivity and reliability of panoramic radiographic signs and cone-beam computed tomography in the assessment of a superimposed relationship between the impacted mandibular third molars and mandibular nerve: A comparative study. $\mathrm{J}$ Ind Acad Oral Med Radiol. 2017;29(2):100-8.

19. Jung YH, Nah KS, Cho BH. Correlation of panoramic radiographs and cone beam computed tomography in the assessment of a superimposed relationship between the mandibular canal and impacted third molars. Imag scien dent. 2012;42(3):121- 7. 